\title{
Book Catalogs: \\ Prospects in the Decade Ahead
}

BY DAVID G. WEBER

$\mathrm{T}$ HE PAPER that Frederick P. Keppel submitted to the ALA in 1939 serves to remind one of the hazards of forecasting. In his consideration of the library of nineteen years in the future (that is, of 1958), he then made this forecast for catalog cards:

It is now the publisher's business to provide them for new books or other records. For old records we have them telephotoed from the Library of Congress or one of the other central catalogs. When it comes to using the cards, I blush to think for how many years we watched the so-called business machines juggle with payrolls and bank books before it occurred to us that they might be adapted to dealing with library cards with equal dexterity. Indexing has become an entirely new art. The modern index is no longer bound up in the volume, but remains on cards, and the modern version of the old Hollerith machine will sort out and photograph anything that the dial tells it, and, thank heavens, will then put all the cards back in their places. 1

With this as caution against forecasting for nineteen years ahead, I should like to comment on the possible utility of book-form catalogs in the next ten years only. For this purpose one may use the trends of the past two decades to attempt a projection, as well as to review problems in the publication of recent library catalogs in book form. This will permit me to describe some of the hazards that we shall face in the years ahead and some ways that we, as a professional association, may together make this a period of fruitful experimentation. ${ }^{2}$

It may be said at the outset that this

1 Frederick P. Keppel, "Looking Forward, a Fantasy." The Library of Tomorrow. (Chicago: ALA, 1939), p. 5.

$2 \mathrm{~A}$ shortened version of this article was read at a meeting of the ALA Book Catalogs Interdivisional Committee, Cleveland, July, 1961.
Mr. Weber is Assistant Director of Libraries, Stanford University.

study results in renewed confidence in the importance of card catalogs. There does seem to be a recent increase, however, in the number of book catalogs issued on the initiative of the library; yet it may be too early to call this a trend toward somewhat greater use of the book catalog as replacement for the card catalog. And the book catalog manifestly has the same advantages and disadvantages today as a hundred years ago.

Let me set the stage for our considerations by giving two views of the present inadequacy of card catalogs. In a recent lecture at the Massachusetts Institute of Technology, Dr. John G. Kemeny reminded his audience of the increase of book production, the increased ease of publication through photographic techniques, the publishing activities that are now mushrooming in formerly undeveloped areas of the world, and the phenomenal rate of library growth. Dr. Kemeny has grown so concerned with this impossible situation as to suggest that, by 1980, the United States government and one hundred research libraries should cooperate to build an automated "national research library" based on high reduction microfilm storage, longdistance telephone dialing for retrieval, and local print-out of copies on regular microfilm or full-size sheets. This proposal by the chairman of Dartmouth's department of mathematics and astronomy should not be taken lightly.

A second example may be found in the recent attempt of Harvard, Yale, 
and the New York Public Library to join forces to solve a common problem. This problem they described thus:

A crisis has been reached in the development of card catalogues for the largest research libraries of this country. These catalogues, which are mechanisms meant to serve scholars, are becoming more and more enormous and complex jungles of cards. It costs great sums to maintain them, unit costs increase steadily as they become more bulky, and they outgrow the space that is readily available for housing them. In spite of all the money and labor that is being invested in cataloguing ... those who use the catalogues and those who make them are increasingly dissatisfied. . . . A bold approach on some new basis seems to be in order. ${ }^{3}$

These libraries saw three alternatives which might be developed singly or in combination with one another. First, the card catalog might prove to be preferable to anything else, and its undesirable features might have to be accepted as lesser evils. Second, a printed catalog - possibly a joint printed catalogmight be practical in spite of the high cost and numerous difficulties it would involve. Third, electronic solutions might be provided by new developments in technology. It may be reported that the three libraries held several meetings to consider the possibility of printing a joint catalog; however, agreement could not be reached.

The card catalog has served libraries well during the past century, but it cannot continue to serve research libraries adequately if cataloging techniques and catalog apparatus remain unchanged. These two examples may show that there is concern for the future of card catalogs-at least in the larger research libraries. And the problems faced by these larger libraries are the ones that will be faced by the medium-size libraries in another generation or two.

3 Annual Report for the Year 1955-56. Cambridge, Mass.: Director, Harvard University Library, p. 6.
In order to see clearly the present condition of card catalogs, it may be well to turn attention briefly to their development during the past century.

Until this century, libraries made extensive use of printed catalogs in book form to answer the common question, "Is the book I want in the library?"

Over a thousand such catalogs were published in the United States between 1723 and 1875. A library such as that of Amherst College would sell one hundred copies of its book catalog within four years of publication; and the Detroit Public Library would sell six hundred copies within seven years and give away four hundred more.

Then came the problem of larger and larger catalogs, resulting from greatly increased acquisitions; and the libraries of the country changed to the card form, applying practices developed between 1847 and 1861. This was no sudden and complete change of library technique, and we are all aware that American libraries keenly debated the two systems throughout the remainder of the century. The involved arguments may be summarized by using Cutter's several points which he wrote down in 1876 ;

The advantages of a printed catalog are briefly:

That it is in less danger of partial or total destruction than a manuscript volume or drawers of cards.

That it can be consulted out of the library.

That it can be consulted in other libraries and it may always fairly be questioned by trustees how far the benefit to any other library is a justification for incurring the expense of printing.

That it is easier to read than the best manuscript volume and very much easier to consult. Here again everything depends on the hurry or impatience of those who consult the catalog. If that is so great that a very slight impediment will cause them to give up the search altogether or never undertake a search after having failed 
once, printing is necessary; but in college and country libraries, this can hardly be the case.

That several persons can consult multiple copies of it at once.

The disadvantages of a printed catalog are:

That it is costly and, if full and accurate, very costly.

That a mistake once made is made forever.

It is out of date before it is published. As it cannot contain the newest books, the very ones most sought for, fresh supplements are continually needed, each of which causes an additional loss of time and patience to consulters. The average man will not look in over four places for a book. A few very persevering or driven by a great need will go as far as five or six. It becomes necessary, therefore, if the cata$\log$ is to be of any use, to print consolidated supplements every five years, and that is expensive. ${ }^{4}$

The turn of the century saw discussions shift from this debate on form of catalog to concentration on rules for individual entries. This concern with the degree of bibliographic information is well summarized by Keyes D. Metcalf in his volume on library administration:

Librarians tended to line up in two camps. One was made up of reference librarians and of catalogers who were "perfectionists," represented by Miss Isidore Mudge and Miss Minnie Sears. They believed that unless very accurate and detailed cataloging rules were followed, the catalog would sooner or later have to be done over and that the extra cost of originally doing it well would not only make better reference work possible, but save money in the long run. The other group was led by Dr. E. C. Richardson, then of the Princeton University Library, who believed that a "title-a-line" cataloging would make readily available perhaps ninetyseven percent of all books and reduce cataloging costs to such an extent that enough additional books could be purchased and cataloged as to more than

4 C. A. Cutter "Library Catalogues," Public Libraries in the United States of America. . (Washington, U. S. Bureau of Education, 1876), Pt. 1, p. 552-54. make up for the three percent lost through the simplified methods. . . . The struggle still goes on. ${ }^{5}$

It may be said, however, that in the United States the period from 1876 to 1941 was the era of the card catalog in complete dominance. Perhaps this period of virtuosity ended with the recall to duty clearly sounded in Andrew Osborn's "Crisis in Cataloging." The integrity of the card catalog's meticulously detailed entries had been strikingly challenged.

In 1942 the era of the marriage of the card catalog and the book form catalog was ushered in with the great Catalog of Books Represented by Library of Congress Printed Cards. The word "marriage" is used since in the present era it is not a case of "either or." It is doubtful if the recent publication of any card catalog in book form has resulted in the complete discarding of the original card file. In these years, the question of format which was tabled in 1901 has been reopened for further discussion. It is still complicated by the continuing divergence of opinion as to the amount of necessary catalog information.

The past twenty years have seen the publication of over sixty library catalogs of American educational institutions. (These are listed in the appendix to this article; and it should be pointed out that in the last two years all but four were publishing ventures of $\mathbf{G}$. K. Hall \& Co.) These catalogs are occasionally substitutes for the cards, but generally are copies of the card catalog information. Some of them give book numbers; a few give multiple locations or joint listings. Through analysis of these catalogs, three basic motivations for publication seem discernable:

1. A library's internal concern with providing easier access for its clientele. This may result from one of four pressures:

studies in Library Administrative Problems. (New Brunswick: Rutgers University Press, 1960), p. 60. 
a. Complexity of use, since a book catalog provides simplicity of presentation and may include exceptional fullness in detail.

b. Geographical dispersal of library units and availability of a single book collection in several locations.

c. Fluidity of collections where the changing catalog record can be provided by mechanical reproduction of a central master file.

d. Physical problems of card catalog space.

2. Local pride and an interest in scholarship generally, which usually results in a subsidized publication.

3. The interest in a particular catalog shown by scholars and libraries throughout the country, an interest which may make the catalog commercially practicable.

In its simplest terms, a publication is going to result either from the local library's saying, "I want it published to support my own responsibilities to my clientele," or from friends' encouraging and supporting special collections through endowment or gifts for current use, or from the national community of scholars' saying, "Your collections are so rich or your cataloging analysis so exceptional that we all need access to these records." The latter case results in a feasible commercial enterprise, while the former two require internal fiscal justification.

That these motivations often overlap is demonstrated by the New York Public Library's comment in introducing its catalog of French Revolutionary Pamphlets, $A$ Check List of the Tallyrand \& Other Collections:

A printed check list rather than the customary cataloging on cards was decided upon for the following reasons: (I) The cost of recording a large but specialized collection would be considerably reduced, and at the same time material would be more easily accessible to students than if cards for each individual piece had been inserted in the public catalog. (2) The entries for the Tallyrand Collection would be kept together. (3) The use of the pamphlet by students would be facilitated. ${ }^{6}$

The three basic motivations are likely to retain their force in the future. Catalogs will be issued for current asquisitions, and they will be issued for older materials. Some will be limited in scope, and some will be comprehensive. Some will be issued by large libraries and many by small.

Since 1942 several techniques have been developed for the production of these catalogs. The study by Professor Richard Shoemaker of Rutgers University $^{7}$ and the analysis by George Piternick, then of the University of California, ${ }^{8}$ describe the methods that are now available through technological developments. Machines and photographic applications that are in hand or are being developed seem certain to revolutionize the production of small editions.

This, then, is the situation in 1961. Let me now turn to the future. As a profession we have learned a good deal from the experience of the last twenty years. However, there are difficulties yet to be surmounted if we are to achieve anything close to ideal standards for publishing book catalogs. Some of the more important problems are the following six:

1. The difficulty of choosing which of several catalogs it is most desirable to publish.

The scholar and the librarian would hope in theory that what money is available to a library could be spent to cover the entire range of knowl-

- Horace E. Hayden, comp., French Revolutionary Pamphlcts; $A$ Check List of the Tallyrand $\mathcal{E}$ Other Collections. ([New York]: New York Public Library, 1945 , p. [iii]).

7 Richard H. Shoemaker, "Some Twentieth Century Book Catalogs," Library Resources and Technical Serv-

icrs. IV (1960), 195-207. Catalog and Its Supplements." (MS, June 1960). 
edge, and that each thorough bibliographical index which is purchased would cover one clearly defined portion of knowledge. The several portions that are purchased by a library should form a composite whole, with as little duplication and as few gaps as possible. This is difficult to achieve. In other words, the "ideal" catalog, to be worthy of publication and to be worthy of purchase by subscribing libraries, must thoroughly index a collection of notable distinction in its particular field. This field should be rather closely and carefully circumscribed in order that it not impinge on catalogs that already have been published or will be published in related areas.

The Oriental field may be used as an example of this point. Is the New York Public Library's Oriental catalog as significant for scholars as that of the Harvard Yenching Institute catalog, of which the first three volumes, from 1938 to 1940, have already been published? Or, in another field, one may ask whether the publication of the New York Public Library Slavonic Division catalog did damage to the possibility of publishing the Cyrillic Union Catalog at the Library of Congress. In this instance, there are reasons to publish both catalogs; for the New York Public Library Slavonic catalog lists some Slavic titles not in the Cyrillic Union Catalog, and it includes a large number of analytics and books in Western languages that are not in the Cyrillic Union Catalog. On the other hand, the Cyrillic Union Catalog includes about twice the five hundred thousand entries in the New York Public Library catalog, while a recent sample indicates that it contains cards for only about one-third of Russian language publications actually available in research libraries other than the Library of Congress. However there is a large, and theoreti- cally wasteful, overlap betweeen the two catalogs.

These examples may indicate the importance of publishers', scholars', and librarians' working together to utilize to best advantage the newer techniques and the funds that are available. How can we find the ideal portions of knowledge having comprehensive collections carefully cataloged in depth? Obviously the quality of the collection is of major importance. I shall return later to this point.

2. The problems concerning the depth of indexing.

All libraries are faced with the dilemma that the cost of buying books is in competition with the expense of cataloging these books. Although cataloging perfectionism is a roadblock to adequate library services, full catalog records are of clear value from a national point of view. For an example, I may mention two collections in the Oriental field, the catalogs of either one of which might deserve publication. One is the New York Public Library's catalog of its Oriental collection, which lists 65,000 volumes indexed on 352,000 cards. The other is the collection of the London University School of Oriental and African Studies, which has 400,000 volumes controlled by only 300,000 cards. One collection is obviously given much more thorough cataloging treatment, and the larger collection covers a much wider subject field. Here is indeed a dilemma.

3. Network complications-the problems of combined use of both the book form and card form catalogs.

Picture, if you will, the largest card catalog you have seen and transfer 80 per cent of it to book form. You would then need to devote almost as much space to the combination card-andbook catalog under these new conditions because of the fact that the cata$\log$ needs to be adequately spread out 
so that many persons may have access to the records at one time. You might, therefore, have on one side of the "index room" the card file for recent accessions. On the other side of the room you might have a book catalog laid out on a counter, or perhaps the catalog in duplicate on two rows of shelves above a counter. There will be questions in the reader's mind as he enters the room and wonders in which catalog to look. The book catalog may be interleaved and annotated for additions or the supplementary materials may be in the card catalog awaiting the next round of book publication. There may be several author and several subject catalogs, some of which may be union catalogs. This will be quite a different type of bibliographical facility from that we are accustomed to using, and the network of bibliographical controls is bound to be a bit more complicated than the single dictionary card file.

4. The major problem of supplements. What is to be done with records for books acquired after a catalog is published? Or, indeed, what happens as books are withdrawn or transferred to different locations? It is conceivable that publishing costs will be reduced to such a level that catalogs may be reprinted frequently with corrections and additions. (However, such a program would probably require the maintenance of a complete card file and thus eliminate any possibility of a sizable space saving which would stem from discarding the card catalog entirely. The Stanford Library would still have to maintain three thousand trays of cards, and I am sure the library staff would find it much more efficient to use the card file than the book for most of its searching processes.) If catalogs are now to be periodically reprinted, they will probably have to be issued in some such format as the telephone book, with inexpen- sive paper and the cheapest of bindings. And, since even inexpensive reprinting is a costly job, some supplements will be necessary. May one accept a state of uncumulated supplements in, say, twenty-year intervals? Or fifty-year intervals?

Deletions will also be a problem, and they will damage the basic set as well as its supplements. Books deleted may often be removed to a regional storage library and the master copy of the catalog so annotated. It also seems possible that the book form catalog is ideally suited as the sole cata$\log$ for books sent to storage, since those records would be seldom altered; it may also have application for regional storage libraries. However, what happens to the National Union Catalog as transfers and withdrawals become common?

It is too early to determine or propose the optimum publication pattern. Rather, libraries of the country may have to live through a few decades of experience with book catalogs before arriving at a generally satisfactory solution to the problem of continuations. For the present, one is led to assume a general pattern not radically different from the examples of the past twenty years, ${ }^{9}$ and to suggest that the two best patterns are to issue supplements either frequently, and cumulated, or to issue them infrequently.

5. The challenge of combination.

There would be distinct advantage to the scholarly world by combining the catalog listing of two or three of the greatest collections in the same field. This is the sort of ideal which was explored by Harvard, Yale, and the New York Public Library back in 1956, and, of course, it was achieved in such union lists as Pollard and Redgrave and the Union List of Serials. Can it

${ }^{\circ}$ This is supported by the study of Mildred C. $O$ 'Connor, "Aspects of Frequency Factors and Patterns of Supplements." (MS, January 1960). 
not be extended to subject fields? There are three or four excellent collections of French Revolutionary pamphlets; it would be salutary to combine the records and issue a catalog which would be definitive. Hopefully, the extra editorial expenses would be balanced by the savings to be derived from libraries' buying one catalog rather than three. Of course, there are problems with differing catalog rules, arrangement of information, filing order, and card legibility; but we can remind ourselves that in the National Union Catalog for 1952-55 the information is readily available in remarkably fine format. More of such accomplishments are to be encouraged.

6. The physical format of the volume. There is always the temptation for the publisher to cut corners in typographic layout, in illustration, in the quality of binding, the quality of paper, and so forth. The publication of a set like the new British Museum catalog with volumes weighing up to seven pounds eight ounces is disappointing when five and one half pounds is a reasonable weight limit. Since photography will enable libraries to print catalogs without retyping their cards, a sequential camera technique designed to handle $3 \times 5$ cards holds more promise than does a machine requiring tabulating cards; yet here again there is danger of accepting a product inferior in appearance.

The six problems here mentioned come in infinite variety. I should like to comment on one particular aspect of commercialism which may undermine achievement of an ideal publication. It was earlier stated that the quality of the collection being indexed is of major importance. This is obvious; but what if publication of a catalog of a collection of second quality is commercially attractive?

May it be possible to offer sound guid. ance for the future publication of book catalogs? Such guidance should be designed to reduce unnecessary overlap, to concentrate on collections of first importance, and to select where possible those collections which have received bibliographical control of a high order. ${ }^{10}$ This is a difficult matter, but I would suggest an evaluative approach which the library profession might pursue in collaboration with scholars. It is the primary responsibility of the librarian to see that standards are here achieved; commercial firms by their nature do not have the time to go into this to the extent which is necessary.

There are several techniques for evaluating the relative strengths of several collections covering the same field. As one example, in 1942, the ALA published LeRoy Merritt's "index of distinctiveness" to research library collections. ${ }^{11}$ In the publication of book catalogs, of course, such a technique would need to be applied to specific subject areas. I also refer to the study of Vaclav Mostecky which sketches five methods of checking the quality of library collections and describes the check list method which was selected for the Slavic study. ${ }^{12}$ It is a good example of application to one specific field.

I hasten to add that such comparisons of library strengths would have to be supplemented with information as to the quality of the bibliographical records, the amount of analytical detail, the physical condition of the catalog, and the extent to which the catalog records already appear in published union catalogs or in special catalogs for related subject areas. This panoply of information-surely never heretofore gathered for a commercial undertaking-would

\footnotetext{
10 "Intellectual and Bibliographical Standards for Book Catalogs" was a study of Robert D. Stevens. (MS, January 1960).

${ }^{11}$ LeRoy C. Merritt, "Resources of American Libraries: a quantitative picture." Robert B. Downs, ed., Union Catalogs in the United States. (Chicago: ALA,

1942), p. 58-96. Collections." Melville J. Ruggles and Vaclav Mostecky, Russian and East European Publications in the Librar. ies of the United States. (New York: Columbia University Press, 1960), p. 228-249.
} 
offer desirable guidance for publishing in the national interest some of America's great library card catalogs.

Considering all aspects of bibliographic control, there are major obstacles to a wholesale replacement of cards by books. This point is made even more strongly by Agnes Tysse. In commenting on the possibility of publishing the complete dictionary catalog, she states that without any doubt the card catalog must remain: "In view of the experience of such libraries as the Library of Congress and Princeton with their printed catalogs, it is questionable if printed book catalogs can ever fully supersede the flexible card catalog, that ingenious, if cumbersome and expensive device so adaptable to additions and changes." However, she continues, "there is no question but that reference and other service librarians and divisional librarians would welcome printed book cata- logs as additions to the complete, upto-date central card catalog." 13 This duplicate reliance has been the pattern developed during the past twenty years. The next decade may see more independent use of book catalogs, in most instances supplemented by card files. The patterns will vary considerably.

Book catalogs have returned after a lengthy retirement. Here is an important aspect of librarianship which will save library card catalogs from "breaking down" and growing to chaotic proportions. Although the "ideal" book catalog seems a myth, the book catalog is going to be the salvation of the card catalog. Librarians, scholars, and publishers must strive for adequate bibliographical standards and suitable physical standards for these important catalogs on which the library world is certain to rely in the decade ahead.

${ }^{13}$ Agnes N. Tysse, "Card Catalogs Versus Printed Book Catalogs and the Catalog User." (MS, March 1961).

\section{APPENDIX: List of Some United States Library Book Catalogs}

1942-Library of Congress, Catalog of Printed Cards (and continuations). University of Michigan, Clements Library, Guide to the Manuscript Collections.

Newberry Library, Checklist of Courtesy Books.

1943-New York Public Library, Catalog of the Arents Collection, vol. 4 (and continuation).

Yale University Library, Catalog of the Harvey Cushing Collection.

1944-Boston Medical Library, Catalog of Incunabula and Early Manuscripts.

1945-New York Public Library, Checklist of French Revolutionary Pamphlets.

1946-St. John's Seminary, Estelle Doheny Library Catalog (supplementing 1940 catalog and concluded in 1955).

1947-University of Pennsylvania Library, Catalogue of the T. Edward Ross Collection of Bibles.

1948-Army Medical Library, Catalog of Printed Cards (and continuations).
1949-Huntington Library, Catalog of $\mathrm{Mu}$ sic Printed Before 1801.

Newberry Library, Guide to the Burlington Archives.

1950-Newberry Library, Checklist of French Political Pamphlets, 15601653.

Wake Forest Coliege Library, Catalogue of the Library of Charles Lee Smith.

1951-King County Library, Seattle, Branch Catalog.

Newberry Library, Guide to the Illinois Central Archives.

Yale University Library, Catalog of the Beinecke Stevenson Collection (continued in 1952 and 1956).

1952-Princeton University Library, Cata$\log$ of the Gallatin Beardsley Collection.

Yale University Library, Catalog of Manuscripts in the Coe Collection of Western Americana.

1953-Harvard University, Lamont Library Catalogue. 
Newberry Library, Catalog of the Greenlee Collection of Portuguese Materials.

Temple Tifereth Israel, Columbus, Ohio, Minnie Cobey Memorial Library Catalogue.

1954-Library of Congress, Catalog of the Lessing J. Rosenwald Collection. Massachusetts Historical Society, Contents of the Microfilm Reels of the Adams Papers.

Southern Newspaper Library, Catalogue.

1955-Library of Congress, Checklist of Microfilms in the British Manuscripts Project.

Los Angeles County Public Library Catalog.

1956-New York State Library, Checklist of Books and Pamphlets... (and continuations).

Newberry Library, Calendar of Philippine Documents in the Ayer Collection.

1957-University of California Library (Berkeley), Index of the Microfilm Collection of German Foreign Ministry Archives.

Cornell University Library, Catalog of the Emanuel Wordsworth Collection.

1958-University of California Library (Berkeley), Catalog of Japanese American Evacuation and Resettlement Material.

Columbia University Libraries, Avery

Architectural Library Catalog.

Hunt Botanical Library Catalog.

Princeton University Library, Cata$\log$ of the Hamilton Collection of American Illustrated Books.

Yale University Library, Catalog of the Faber du Faur Collection of German Baroque Literature.

1959-Columbia River Regional Library Demonstration, Wenatchee, Catalog. Harvard University Library, Catalog of the Kilgour Collection of Russian Literature.

New York Public Library, Dictionary Catalog of the Slavonic Collection.

Newberry Library, Catalog of Printed Materials Relating to the Philippine Islands.
Henry Shelton Sanford Memorial Library, Sanford, Florida, Catalogue of Books.

1960 - Boston University Library, Catalog of African Government Documents and African Area Index.

Cornell University Library, Catalogue of the Icelandic Collection.

Insurance Society of New York Library, Life Insurance Catalog.

New York Academy of Medicine Library, Biographical Catalog.

New York Academy of Medicine Library, Illustration Catalog.

New York Academy of Medicine Library, Portrait Catalog.

New York Metropolitan Museum of Art, Library Catalog.

New York Public Library, Dictionary Catalog of the Jewish Collection.

New York Public Library, Dictionary Catalog of the Oriental Collection.

New York State Library, The Gotshall Collection.

Newberry Library, Genealogical Index.

University of Pennsylvania Library, Catalog of the E. F. Smith Memorial Collection in the History of Chemistry.

University of Pittsburgh Library, Catalogue of the Manuscripts and Printed Music of Adolph M. Foerster.

Yale University Library, Catalogue of the Collection of Pequot Library.

1961-Free Library of Philadelphia, Catalog of the Carson Law Collection.

New York Public Library, Dictionary Catalog of the History of the Americas Collection.

New York Public Library, Subject Catalog of the World War I Collection.

Newberry Library, Catalog of the Edward E. Ayer Collection of Americana and American Indians.

Newberry Library, Dictionary Cata$\log$ of the History of Printing from the John M. Wing Collection.

University of Pennsylvania, Catalog of the Programmschriften Collection. Yale University, Catalog of the Yale Collection of Western Americana. 